\title{
Heavy metals contents on beach sediments north and south of Sohar industrial area, Oman.
}

\begin{abstract}
total of 63 surface sediment samples from three sites: Harmul north of Sohar industrial area, Majees south of Sohar industrial area and Zafaran nine kilometers south of Majees were collected in November 2005. They were analyzed for 11 heavy metals including: Vanadium $(\mathrm{V})$, chromium $(\mathrm{Cr})$, manganese $(\mathrm{Mn})$, nickel $(\mathrm{Ni})$, copper $(\mathrm{Cu})$, selenium $(\mathrm{Se})$, mercury $(\mathrm{Hg})$, cadmium $(\mathrm{Cd})$, lead $(\mathrm{Pb})$, zinc $(\mathrm{Zn})$ and arsenic (As) using microwave digestion followed by Inductively Coupled Plasma-Mass Spectrometry (ICP-MS). The concentrations of chromium, manganese and vanadium were higher in Harmul than Majees and Zafaran. Arsenic concentration was generally low except in some stations. The results revealed that heavy metals concentrations in these sites are not alarming.
\end{abstract}

Keyword: Heavy metals; Sediments; Sohar; ICPMS; Microwave digestion. 